\title{
Development of High-performance Single Layer Weft Knitted Structures for Cut and Puncture Protection
}

\author{
Fangueiro $\mathbf{R}^{1 *}$, Carvalho $\mathbf{R}^{1}$, Silveira $\mathbf{D}^{1}$, Ferreira $\mathbf{N}^{2}$, Ferreira $\mathbf{C}^{2}$, Monteiro $\mathrm{F}^{2}$ and Sampaio $\mathbf{S}^{1}$ \\ ${ }^{1}$ Center for Textile Science and Technology, University of Minho, Guimarães, Portugal \\ ${ }^{2}$ A Ferreira e Filhos S.A., Vizela, Portugal
}

\begin{abstract}
The number of violent situations against security agents using cut and puncture elements, like knives and needles, are increasing daily all over the world. There is a real need for the development of flexible materials able to protect these security professionals without compromising their comfort in different working conditions. The aim of this study is to develop single-layer weft knitted fabrics for cut and puncture protection to be used as protective clothing. Three different weft knitted structures were selected (single jersey, crepe, and moss tuck stitch) in order to study the effect of the yarn arrangement on cut and puncture performance. Different knitted fabrics have been produced with different materials including ultra-high molecular weight polyethylene, para-aramid, high tenacity polyester, high tenacity polypropylene and high tenacity polyamide. In order to study the performance of each structure in combination with the different materials, samples were tested according to EN 388. It was proved that due to the tuck stitches, crepe and moss structures improved cut and puncture performances in comparison with jersey structures. The conical puncture resistance was mainly attributed to the structure (high friction between the yarns and within the yarns due to the dense structure), the knife puncture resistance was mainly attributed to the strength of the yarns, and the cut resistance was mainly attributed to the structure (stretching and thickness) and to the mechanical properties of the yarns. Based on the experimental results and according to EN 388 test classification, moss tuck stitch structure produced with ultra-high molecular weight polyethylene presents the highest cut resistance, classified as level 5 , and the highest conical puncture resistance, level 4. Crepe structure produced with para-aramid presents the highest knife puncture resistance. It is suggested the use of single layer moss tuck stitch fabric produced with ultra-high molecular weight polyethylene as protective clothing.
\end{abstract}

Keywords: Cut; Puncture; Protection; Tuck stitch; Ultra-high molecular weight polyethylene (UHMW-PE)

\section{Introduction}

The number of violent situations against security agents using cut and puncture elements, like knives and needles, are increasing daily all over the world. There is a real need for the development of flexible materials that are able to protect these professionals without compromising their comfort in different working conditions. Materials normally used in the equipment for personnel protection are usually based high performance fibers like glass, carbon or ultra-high molecular weight polyethylene (UHMW-PE) blended with conventional fibers like polyester, cotton or polyamide to provide the required comfort and flexibility [1]. Ideally, such garments should be flexible, pliable, soft and cut/abrasion resistant. Unfortunately, any improvement in the cut and/or abrasion resistance has usually been at the sacrifice of the other properties. In addition, if puncture resistance is needed, multiple layers of woven fabric are typically required, particularly made from high strength performance yarns, such as aramid [2]. Often, in knit fabrics, puncture resistance has been extremely difficult, if not impossible, to achieve due to knit stitches often being able to have mobility thus "robbing" yarn from adjacent stitches to open a hole in the fabric, without cutting or tearing the yarns [2]. Knitted fabric was seldom commended to be used as stabresistant materials. But studies have also pointed out that the protective material based on knitted structure had the features of low weight, better designability, fulfilling wide-area protection, etc., [3]. Polo et al. reported that the multi-layer knitted fabric could absorb penetration energy, and possessed a fairly well shearing resistance, of which stitches locked the knife to stop penetrating before the fabric was destroyed completely [4]. Yao et al. [5] claimed that weft-knitted structure could resist stronger penetration force through the deformation of weft loops and self-locking, anyhow, it was self-evident that fabric had a larger deformation, and a deeper penetration. Lijuan et al. [6] investigated the structure and property of stab resistant warp-knitted single-face fabric. The study found that the underloop structure peculiar to warp-knitted fabric could stabilize the stitch, and added the yarn's agglomeration around knife edge, which had an obvious advantage in penetration force and yarn strength efficiency. The above studies revealed that the textile structure mainly suffered shearing and tensile action when the knife penetrated into the fabric. High-strength and good shearingresistant fibers combining with tight textile structure contributed to a good stab resistance. Besides, the fabric distortion could absorb the penetration energy which could improve the stab.

The aim of this study is to develop single-layer weft knitted fabrics for cutting and puncture protection to be used as protective clothing for police agents, body-guards, etc. Different knitted fabrics have been produced in an electronic flat knitting machine: single jersey, crepe, and moss tuck stitch, using variations on normal and tuck loops in the coursewise and walewise directions. The selection of these structures was justified by their distinct deformation geometry. Previous studies showed that low deformation structures could absorb penetration energy easily, which could improve the stab resistance [4-6]. These two technological parameters are indicated in the literature as among the

*Corresponding author: Raul Fangueiro, Center for Textile Science and Technology, University of Minho, Guimarães, Portugal, Tel: + 351253510 204; E-mail: rfangueiro@civil.uminho.pt

Received November 30, 2015; Accepted December 07, 2015; Published December 15, 2015

Citation: Fangueiro R, Carvalho R, Silveira D, Ferreira N, Ferreira C, et al. (2015) Development of High-performance Single Layer Weft Knitted Structures for Cut and Puncture Protection. J Textile Sci Eng 5: 225. doi:10.4172/2165-8064.1000225

Copyright: (c) 2015 Fangueiro R, et al. This is an open-access article distributed under the terms of the Creative Commons Attribution License, which permits unrestricted use, distribution, and reproduction in any medium, provided the original author and source are credited. 
most important factors of influence for the knitted fabrics.

Herein, it will be shown how the structure has a clear influence on elongation due to the specific geometry of each structure (jersey, crepe and moss) and how it improves stab resistance performance.

Fabrics have been produced with different materials including ultra-high molecular weight polyethylene (UHMW-PE), para-aramid (p-AR), high tenacity polyester (PES HT), high tenacity polypropylene (PP HT) and high tenacity polyamide (PA HT). In order to study the performance of each structure in combination with the different materials, samples were tested under shear and puncture, according to EN 388 .

\section{Materials and Methods}

\section{Yarns}

High performance fibres based yarns, namely high tenacity polyester (PES HT), high tenacity polyamide (PA HT), high tenacity polypropylene (PP HT), ultra high molecular weight polyethylene (UHMW-PE), and para-aramid were used to compare the stab and puncture resistance performances of different weft knitted fabrics. Five specimens of high performance fibres based yarns were tested according to NP EN 2060, ASTM 3108, ASTM 3412 and NP EN 2062, to determine their yarn linear density, coefficient of friction and tensile properties. The yarn testing results are summarized in Table 1.

\section{Knitted fabrics}

Single jersey, crepe and moss tuck stitch weft knitted fabrics were produced for this research (Figure 1) on a E10 Stoll electronic flat knitting machine, with similar adjustment parameters namely cams settings, yarn feeding tension and fabric take down. In single jersey structure just normal loops on a single needle bed are used; in the crepe structure normal and tuck loops are combined in a single needle bed; in the moss tuck stitch structure the front and back needle beds are utilized to combine tuck and normal loops. Table 2 shows the physical characteristics of the weft knitted fabrics produced.

\section{Puncture and cut}

The puncture resistance using conical and knife probes was evaluated using a Hounsfield H $100 \mathrm{KS}$ universal equipment (Figure 2a), with a cross-head speed of $100 \mathrm{~mm} / \mathrm{min}$ and with $20 \mathrm{~mm}$ distance between the probe and the specimen, according to EN388 standard. The probe (Figures $2 \mathrm{~b}$ and $2 \mathrm{c}$ ) is pushed through the material at a fixed speed and the force required to penetrate through the material is measured. The maximum load, extension and energy of penetration were measured and averaged for five samples. Load-displacement curves were established and the deformation of the knitted fabrics in the penetration area analyzed.
Cut resistance performance was evaluated according to standard EN388 for two samples with five cuts each, using Coup test device (Figure 3). This device consists of a circular free-rotating blade, under pressure from a standard weight $(5 \mathrm{~N})$, which is moved backwards and forwards over the surface of the specimen over a fixed stroke length. Number of cycles required for the blade to cut through the material is used to calculate the Cut Index, varying from 0 to 5 ( 5 represents the highest performance level).

\section{Results and Discussion}

\section{Puncture with a conical probe}

Conical probe puncture occurs in four different stages: (i) contact pressure of the tip of the conical probe against a fabric; (ii) slippage of the tip into both within yarns and between yarns, resulting in puncture; (iii) friction of the fabric against the conical section of the point; and (iv) slippage of the conical section through the fabric $[7,8]$. Resistance to conical probe puncture is however a much more complex problem as it also requires full consideration of the tightness of the fabric and of the profile of the puncture element. A dense structure is beneficial in resisting the conical puncture probe [9]. A high density fabric restricts the mobility of the yarns, which induces the increase of the inter-yarn friction and due to the friction within and between the yarns that increases the absorption energy. When the conical probe cannot perforate the fabric, the yarns are easily deformed through slipping over each other in the walewise and coursewise directions to allow absorbing more energy and increasing the resisting force for probe penetration, leading to a higher puncture resistance.

As can be seen in Table 3, structure 1 (single jersey) presents higher energy absorption than structure 2 (crepe) except for UHMWPE. These results may be explained based on the lower elongation of the crepe structure (structure 2) compared to the jersey structure (structure 1). The single layer structure 2 during the resisting force for probe penetration absorbs less energy and it might be due to the tuck stitches within the structures that are at higher stress and that makes the yarns to reach faster the breaking point. As for structure 3 there is an increase in the absorption energy when compared to structure 2 and to structure 1 . Structure 3 when stretched causes the face loop courses to cover the reverse loop courses, making the fabric twice as thick as single jersey [7] which facilitates energy dissipation from the conical probe impactor. The other variable influencing the puncture resistance with the conical probe but to a lesser degree is the mechanical properties of the yarn. The most prominent energy absorption changes were recorded for samples UHMW-PE structure 3, UHMW-PE structure 2 and UHMW-PE structure 1. Energy absorption for fabric UHMW-PE structure 3 increased in the order of $344 \%$ when compared to UHMW-PE structure 2, and structure 2 increased in order of $10 \%$ when compared to UHMW-PE structure 1, emphasising the influence

\begin{tabular}{|c|c|c|c|c|c|c|c|}
\hline Yarn material & $\begin{array}{l}\text { Linear Density } \\
\text { (Tex) }\end{array}$ & $\begin{array}{l}\text { Coefficient of } \\
\text { Friction }(\mu)\end{array}$ & Tenacity (N/Tex) & $\begin{array}{c}\text { Breaking Extension } \\
(\%)\end{array}$ & $\begin{array}{l}\text { Initial Modulus } \\
(\mathrm{GPa})\end{array}$ & $\begin{array}{c}\text { Displacement at } \\
\text { maximum force }(\mathrm{mm})\end{array}$ & Breaking Load (N) \\
\hline PA HT & $\begin{array}{c}47 \\
( \pm 1.7 \%)\end{array}$ & {$[0.43-0.70]$} & $\begin{array}{c}0.70 \\
( \pm 4 \%)\end{array}$ & $\begin{array}{l}16.15 \\
( \pm 5 \%)\end{array}$ & $\begin{array}{c}47.3 \\
( \pm 5 \%)\end{array}$ & $\begin{array}{l}80.72 \\
( \pm 5 \%)\end{array}$ & $\begin{array}{c}67.5 \\
( \pm 4 \%)\end{array}$ \\
\hline PES HT & $\begin{array}{c}55 \\
( \pm 1.6 \%)\end{array}$ & {$[0.45-0.70]$} & $\begin{array}{c}0.53 \\
( \pm 2 \%)\end{array}$ & $\begin{array}{c}12.6 \\
( \pm 6 \%)\end{array}$ & $\begin{array}{c}50.2 \\
( \pm 7 \%)\end{array}$ & $\begin{array}{l}63.00 \\
( \pm 6 \%)\end{array}$ & $\begin{array}{l}29.54 \\
( \pm 2 \%)\end{array}$ \\
\hline PP HT & $\begin{array}{c}110 \\
( \pm 0.7 \%)\end{array}$ & [0.35-0.55] & $\begin{array}{c}0.64 \\
( \pm 5 \%)\end{array}$ & $\begin{array}{l}19.56 \\
( \pm 9 \%)\end{array}$ & $\begin{array}{c}11.8 \\
( \pm 17 \%)\end{array}$ & $\begin{array}{l}97.81 \\
( \pm 9 \%)\end{array}$ & $\begin{array}{l}71.68 \\
( \pm 5 \%)\end{array}$ \\
\hline UHMW-PE & $\begin{array}{c}176 \\
( \pm 0.9 \%)\end{array}$ & {$[0.31-0.37]$} & $\begin{array}{c}2.70 \\
( \pm 7 \%)\end{array}$ & $\begin{array}{c}8.56 \\
( \pm 36 \%)\end{array}$ & $\begin{array}{c}45.3 \\
( \pm 38 \%)\end{array}$ & $\begin{array}{c}43.01 \\
( \pm 35 \%)\end{array}$ & $\begin{array}{l}476.01 \\
( \pm 7 \%)\end{array}$ \\
\hline p-AR & $\begin{array}{c}173 \\
( \pm 0.4 \%)\end{array}$ & {$[0.25-0.35]$} & $\begin{array}{l}1.65 \\
( \pm 3 \%)\end{array}$ & $\begin{array}{c}4.37 \\
( \pm 4 \%)\end{array}$ & $\begin{array}{c}47.7 \\
( \pm 31 \%)\end{array}$ & $\begin{array}{l}21.83 \\
( \pm 4 \%)\end{array}$ & $\begin{array}{l}285.64 \\
( \pm 3 \%)\end{array}$ \\
\hline
\end{tabular}

Table 1: Yarn testing results. 


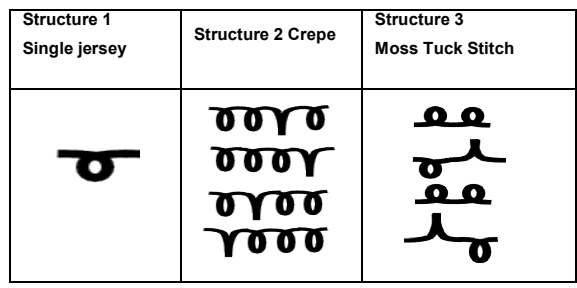

Figure 1: Knitted fabric patterns.

\begin{tabular}{|c|c|c|c|c|c|c|c|}
\hline \multirow[t]{2}{*}{ Structure } & \multirow[t]{2}{*}{ Yarns } & \multirow[t]{2}{*}{$\begin{array}{l}\text { Aerial } \\
\text { mass } \\
\left(\mathrm{g} / \mathrm{m}^{2}\right)\end{array}$} & \multicolumn{2}{|c|}{$\begin{array}{l}\text { Loop Length } \\
\text { (i) } / 100 \text { wales } \\
\text { (cm) }\end{array}$} & \multicolumn{2}{|c|}{ Density } & \multirow[t]{2}{*}{$\begin{array}{l}\text { Tightness } \\
\text { factor }\end{array}$} \\
\hline & & & Normal & Tuck & $\begin{array}{c}\text { wales/ } \\
\mathbf{c m}\end{array}$ & $\begin{array}{c}\text { courses/ } \\
\mathbf{c m}\end{array}$ & \\
\hline \multirow[t]{5}{*}{$\begin{array}{l}\text { Structure } 1 \\
\text { Jersey }\end{array}$} & PES HT & $\begin{array}{l}185.44 \\
( \pm 7 \%)\end{array}$ & $\begin{array}{c}0.66 \\
( \pm 2 \%)\end{array}$ & & $\begin{array}{c}5 \\
( \pm 10 \%)\end{array}$ & $\begin{array}{c}7 \\
( \pm 12 \%)\end{array}$ & 11.24 \\
\hline & PA HT & $\begin{array}{l}160.19 \\
( \pm 8 \%)\end{array}$ & $\begin{array}{c}0.71 \\
( \pm 0 \%)\end{array}$ & & $\begin{array}{c}6 \\
( \pm 0 \%)\end{array}$ & $\begin{array}{c}7 \\
( \pm 6 \%) \\
\end{array}$ & 9.72 \\
\hline & PP HT & $\begin{array}{l}429.42 \\
( \pm 5 \%)\end{array}$ & $\begin{array}{c}0.70 \\
( \pm 0 \%)\end{array}$ & & $\begin{array}{c}5( \pm \\
10 \%)\end{array}$ & $\begin{array}{c}7 \\
( \pm 8 \%)\end{array}$ & 14.16 \\
\hline & UHMW-PE & $\begin{array}{l}519.08 \\
( \pm 7 \%)\end{array}$ & $\begin{array}{c}0.88 \\
( \pm 4 \%)\end{array}$ & & $\begin{array}{c}4 \\
( \pm 0 \%)\end{array}$ & $\begin{array}{c}5 \\
( \pm 10 \%)\end{array}$ & 15.01 \\
\hline & p-AR & $\begin{array}{l}437.75 \\
( \pm 4 \%)\end{array}$ & $\begin{array}{c}0.93 \\
( \pm 4 \%)\end{array}$ & & $\begin{array}{c}4 \\
( \pm 11 \%)\end{array}$ & $\begin{array}{c}6 \\
( \pm 8 \%) \\
\end{array}$ & 14.16 \\
\hline \multirow[t]{5}{*}{$\begin{array}{l}\text { Structure } 2 \\
\text { Crepe }\end{array}$} & PES HT & $\begin{array}{l}287.75 \\
( \pm 8 \%)\end{array}$ & $\begin{array}{c}0.44 \\
( \pm 9 \%)\end{array}$ & & $\begin{array}{c}8 \\
( \pm 7 \%)\end{array}$ & $\begin{array}{c}16 \\
( \pm 4 \%)\end{array}$ & 16.86 \\
\hline & PA HT & $\begin{array}{c}245.83 \\
( \pm 24 \%)\end{array}$ & $\begin{array}{c}0.46 \\
( \pm 9 \%)\end{array}$ & & $\begin{array}{c}7 \\
( \pm 6 \%)\end{array}$ & $\begin{array}{c}15 \\
( \pm 3 \%)\end{array}$ & 14.87 \\
\hline & PP HT & $\begin{array}{l}527.75 \\
( \pm 8 \%)\end{array}$ & $\begin{array}{c}0.56 \\
( \pm 3 \%)\end{array}$ & & $\begin{array}{c}7 \\
( \pm 0 \%)\end{array}$ & $\begin{array}{c}14 \\
( \pm 3 \%)\end{array}$ & 18.8 \\
\hline & $\begin{array}{l}\text { UHMW- } \\
\text { PE }\end{array}$ & $\begin{array}{l}664.33 \\
( \pm 2 \%)\end{array}$ & $\begin{array}{c}0.7 \\
( \pm 1 \%)\end{array}$ & & $\begin{array}{c}6 \\
( \pm 0 \%)\end{array}$ & $\begin{array}{c}10 \\
( \pm 4 \%)\end{array}$ & 18.87 \\
\hline & p-AR & $\begin{array}{c}729.92 \\
( \pm 14 \%)\end{array}$ & $\begin{array}{c}0.7 \\
( \pm 1 \%)\end{array}$ & & $\begin{array}{c}7 \\
( \pm 0 \%)\end{array}$ & $\begin{array}{c}12 \\
( \pm 7 \%)\end{array}$ & 18.71 \\
\hline \multirow{5}{*}{$\begin{array}{l}\text { Structure } 3 \\
\text { Moss Tuck } \\
\text { Stitch }\end{array}$} & PES HT & $\begin{array}{l}532.33 \\
( \pm 4 \%)\end{array}$ & $\begin{array}{l}0.47 \\
( \pm 2)\end{array}$ & $\begin{array}{c}0.47 \\
( \pm 3 \%)\end{array}$ & $\begin{array}{c}8 \\
( \pm 5 \%)\end{array}$ & $\begin{array}{c}8 \\
( \pm 5 \%)\end{array}$ & 15.73 \\
\hline & PA HT & $\begin{array}{l}426.75 \\
( \pm 8 \%)\end{array}$ & $\begin{array}{c}0.50 \\
( \pm 1 \%)\end{array}$ & $\begin{array}{c}0.51 \\
( \pm 1 \%)\end{array}$ & $\begin{array}{c}9 \\
( \pm 0 \%)\end{array}$ & $\begin{array}{c}10 \\
( \pm 5 \%)\end{array}$ & 13.61 \\
\hline & PP HT & $\begin{array}{l}852.75 \\
( \pm 2 \%)\end{array}$ & $\begin{array}{c}0.62 \\
( \pm 1 \%)\end{array}$ & $\begin{array}{c}0.60 \\
( \pm 2 \%)\end{array}$ & $\begin{array}{c}7 \\
( \pm 0 \%)\end{array}$ & $\begin{array}{c}8 \\
( \pm 0 \%)\end{array}$ & 17.15 \\
\hline & $\begin{array}{l}\text { UHMW- } \\
\text { PE }\end{array}$ & $\begin{array}{c}1762.67 \\
( \pm 5 \%)\end{array}$ & $\begin{array}{c}0.68 \\
( \pm 0 \%)\end{array}$ & $\begin{array}{c}0.82 \\
( \pm 1 \%)\end{array}$ & $\begin{array}{c}6 \\
( \pm 0 \%)\end{array}$ & $\begin{array}{c}8 \\
\pm 0 \%)\end{array}$ & 17.65 \\
\hline & $p-A R$ & $\begin{array}{c}1196.83 \\
( \pm 4 \%)\end{array}$ & $\begin{array}{c}0.62 \\
( \pm 2 \%)\end{array}$ & $\begin{array}{c}0.75 \\
( \pm 3 \%)\end{array}$ & $\begin{array}{c}7 \\
( \pm 0 \%)\end{array}$ & $\begin{array}{c}13 \\
( \pm 4 \%)\end{array}$ & 19.18 \\
\hline
\end{tabular}

Table 2: Characteristics of the weft knitted fabrics.
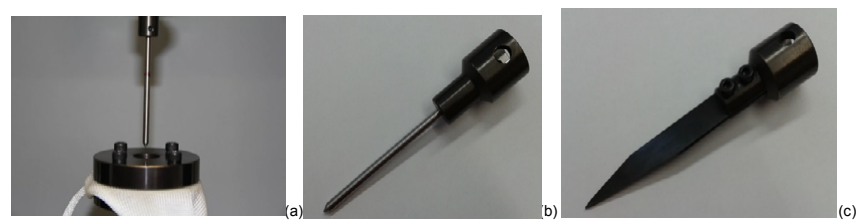

Figure 2: (a) Puncture testing set-up, (b) conical probe, (c) knife probe.

of the structure on the stab resistance. Of all the samples, UHMW-PE structure 3 presents the highest energy absorption capacity.

Figure 4 shows the load-displacement curves for the weft knitted samples tested. Highest energy absorption fabric, UHMW-PE structure 3 , had maximum resistance of $579 \mathrm{~N}$ at $13 \mathrm{~mm}$. Graphics show that the structure has a stronger influence on the conical probe puncture behaviour.

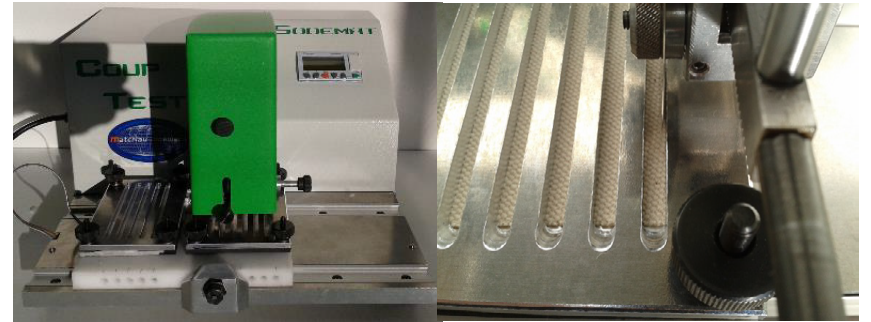

Figure 3: Coup testing device.

\begin{tabular}{|c|c|c|c|c|c|}
\hline $\begin{array}{l}\text { Puncture } \\
\text { probes }\end{array}$ & Structure & Yarns & $\begin{array}{l}\text { Displacement at } \\
\text { max. load (mm) }\end{array}$ & $\begin{array}{l}\text { Maximum } \\
\text { Load (N) }\end{array}$ & Energy (J) \\
\hline \multirow{15}{*}{$\begin{array}{l}\text { Conical } \\
\text { probe }\end{array}$} & \multirow{5}{*}{$\begin{array}{l}\text { Structure } 1 \\
\text { jersey }\end{array}$} & PES HT & 10.180 & 132.82 & 0.3321 \\
\hline & & PA HT & 14.928 & 131.25 & 0.3957 \\
\hline & & PP HT & 13.932 & 398.46 & 0.8632 \\
\hline & & UHMW-PE & 13.956 & 314 & 0.3741 \\
\hline & & p-AR & 16.080 & 581.72 & 1.3400 \\
\hline & \multirow{5}{*}{$\begin{array}{l}\text { Structure } 2 \\
\text { crepe }\end{array}$} & PES HT & 11.500 & 172.4 & 0.2501 \\
\hline & & PA HT & 18.610 & 95.71 & 0.2990 \\
\hline & & PP HT & 13.800 & 364.8 & 0.3648 \\
\hline & & UHMW-PE & 14.082 & 124.802 & 0.4111 \\
\hline & & p-AR & 15.630 & 255.54 & 0.5740 \\
\hline & \multirow{5}{*}{$\begin{array}{l}\text { Structure } 3 \\
\text { moss tuck } \\
\text { stitch }\end{array}$} & PES HT & 11.500 & 254.4 & 0.4281 \\
\hline & & PA HT & 15.280 & 211.36 & 0.7102 \\
\hline & & PP HT & 12.920 & 536.3 & 0.5363 \\
\hline & & UHMW-PE & 13.152 & 579.16 & 1.8201 \\
\hline & & p-AR & 11.862 & 338.64 & 0.7646 \\
\hline
\end{tabular}

Table 3: Puncture testing results.

Images of structure 1, structure 2 and structure 3 produced with PP HT, p- AR and UHMW-PE yarns after conical probe puncture are shown in Figure 5. Structure 1 produced with PP HT shows a permanent hole in the fabric that persisted when the conical probe was removed, it seems that conical probe penetrates the fabrics after fracturing fibres and yarns, as seen in Figures $5 \mathrm{a}$ and $5 \mathrm{~b}$ illustrates damage area of PP HT structure 2 fabric, showing a hole left on the fabric after puncture and some fibres and yarns fractured. The hole of PP HT structure 2 is smaller than the hole of PP HT structure 1 as structure 2 presents tighter structure. The tuck stitches acted holding the structure and limiting the area of damage. From Figure $5 \mathrm{c}$ it is seen that few fibres and yarns are fractured and the hole created by the test is very small. The tight and thick structure 3 in combination with the low initial modulus of PP HT yarns permit elastic deformations that are recoverable upon removal of conical probe. Figure $5 \mathrm{~d}$ shows no fractured fibres and yarns as the conical probe penetrated the fabric primarily by displacing them without damaging. P-AR structure 1 is an open structure produced with a high tenacity yarn thus fabric damage is more likely to be from structure deformation rather than fracturing fibres and yarns. Figure 5e shows few fractured fibres and yarns with a hole in the fabric. In Figure $5 f$ it is evident more fibres and yarn damage when comparing with Figure $5 \mathrm{e}$ and the hole from fabric in Figure $5 \mathrm{f}$ is smaller than from Figure 5e. It may be that p-AR structure 3 offered more resistance to puncture; fibres and yarns could not be pushed to side and the yarns were fractured in order to allow conical probe to pass through the fabric. Figures $5 \mathrm{~g}-5 \mathrm{i}$ follow the same trend as Figures $5 \mathrm{~d}-5 \mathrm{f}$, respectively. Major differences are seen in Figures $5 \mathrm{i}$ and $5 \mathrm{f}$; UHMW-PE structure 3 offered the highest puncture resistance of all samples but it is observed that the part of the fabric that was deflated 

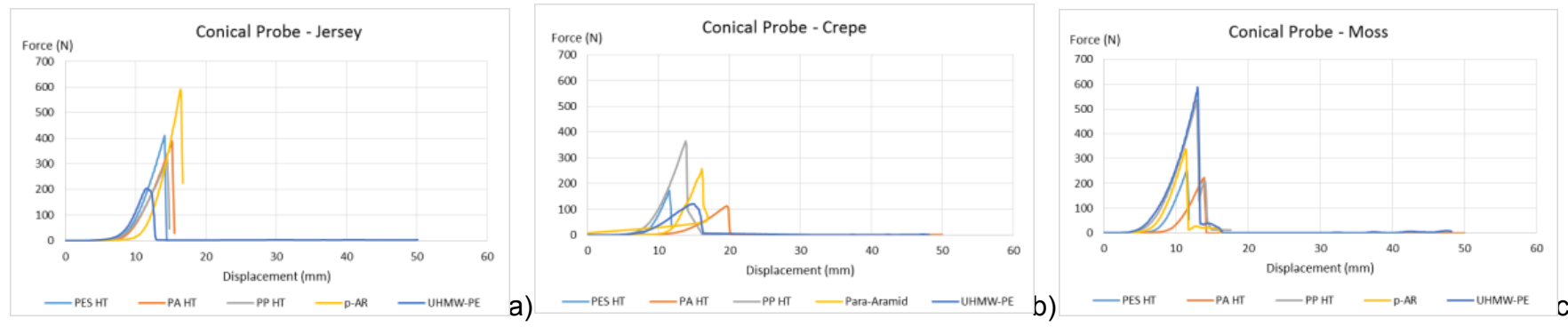

Figure 4: Load-displacement curves for the weft knitted fabrics tested.

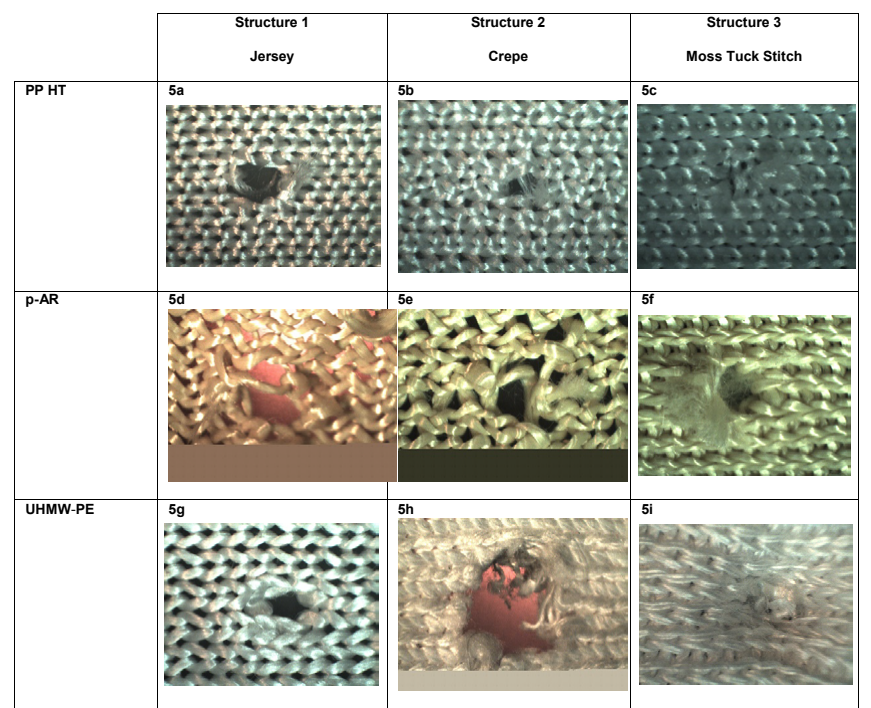

Figure 5: Images of structure 1, structure 2 and structure 3 produced with PP $\mathrm{HT}, \mathrm{p}-\mathrm{AR}$ and UHMW-PE yarns after conical probe resistance test.

after conical probe puncture was not lifted back up, and it might be due to the UHMW-PE yarn that it is a yarn with very high tenacity but very high initial modulus which does not permit elastic deformation recover. It is quite clear from Figure 5 that, in general, all fabrics from structure 1 have the most fabric damage and thus offering less puncture resistance and that all fabrics from structure 3 have the least fabric damage offering highest puncture resistance performance.

\section{Puncture with a knife probe}

During knife probe puncture through a fabric, fibre in contact with the knife edge has high stress and tends to be stretched, and the yarns will move in weft and warp directions, allowing the edge of the knife to pass through. The fabric will be deformed under the build-up force, and the edge of the knife will start to cut the yarn. The resistance to puncture of a knife depends on the material, the cross-section of the yarns, their strength and the support points in the base fabric [10]. Although a tight structure with higher density is helpful to resist puncture, the little slippage space may be a disadvantage for yarns, because they are easily cut directly by the blade of the knife [9].

In general, the energy absorption increases from structure 1 to structure 2 and from structure 2 to structure 3 samples, as can be seen in Table 4 . The moss fabrics present the best knife puncture resistance, followed by the crepe fabrics. These might be explained by the tightness factor showed by crepe structures (Table 2), and the influence of the

\begin{tabular}{|c|c|c|c|c|c|}
\hline $\begin{array}{l}\text { Puncture } \\
\text { probes }\end{array}$ & Structure & Yarns & $\begin{array}{l}\text { Displacement at } \\
\text { max. load }(\mathrm{mm})\end{array}$ & $\underset{\text { load }(\mathrm{N})}{\text { Maximum }}$ & Energy (J) \\
\hline \multirow{15}{*}{$\begin{array}{l}\text { Knife } \\
\text { probe }\end{array}$} & \multirow{5}{*}{$\begin{array}{l}\text { Structure } 1 \\
\text { jersey }\end{array}$} & PES HT & 8.908 & 11.47 & 0.0198 \\
\hline & & PA HT & 8.938 & 13.26 & 0.0238 \\
\hline & & PP HT & 8.308 & 36.462 & 0.0658 \\
\hline & & UHMW-PE & 17.202 & 56.806 & 0.3468 \\
\hline & & Para-aramid & 15.968 & 70.17 & 0.2642 \\
\hline & \multirow{5}{*}{$\begin{array}{l}\text { Structure } 2 \\
\text { "crepe" }\end{array}$} & PES HT & 12.330 & 17.675 & 0.0542 \\
\hline & & PA HT & 21.010 & 23.98 & 0.0902 \\
\hline & & PP HT & 26.130 & 58.5 & 0.4121 \\
\hline & & UHMW-PE & 14.398 & 2.25 & 0.0084 \\
\hline & & Para-aramid & 21.060 & 111.086 & 0.5035 \\
\hline & \multirow{5}{*}{$\begin{array}{l}\text { Structure } 3 \\
\text { "Moss tuck } \\
\text { stitch" }\end{array}$} & PES HT & 7.980 & 42.65 & 0.1257 \\
\hline & & PA HT & 16.020 & 43.62 & 0.1480 \\
\hline & & PP HT & 21.480 & 85.1 & 0.4820 \\
\hline & & UHMW-PE & 6.882 & 48.146 & 0.1048 \\
\hline & & Para-aramid & 17.444 & 89.216 & 0.3862 \\
\hline
\end{tabular}

Table 4: Puncture testing results.

tuck stitches. Anyhow p-AR structure 2 sample showed the highest knife puncture resistance. Structure 3, being a more compact structure, it was expected to present the highest knife puncture resistance, however its tight structure with higher density might explain these failure result.

Fabric damage under the knife is mainly dependent on the mechanical properties of the yarn and less influenced by the fabric structure itself, as can be seen in Figure 6. Highest energy absorption fabric, p-AR structure 2, presents maximum resistance of $111 \mathrm{~N}$ at 21 $\mathrm{mm}$.

Analysing images of structure 1, structure 2 and structure 3 produced with PP HT, p- AR and UHMW-PE yarns after knife probe puncture (Figure 7), it is quite clear that in all the fabrics the area damaged after the knife puncture is higher than that after the conical probe puncture. From Figure $7 \mathrm{a}$ it is found that the dominant failure mechanism is fibre fracture due to cutting; cutting blade of the knife has caused severe and extensive fibre fracture. Significant damage is observed in PP HT structure 2 (Figure 7b). In case of PP HT structure 3 , fibre and yarn cutting is evident, but the magnitude of damage is less compared to PP HT structure 2 and to PPHT structure 1. This might be due to the thickness (twice as jersey) of structure 3, with this additional "layer" structure deformation is less evident. Figures $7 \mathrm{~d}-7 \mathrm{f}$ followed the same trend as Figures $7 \mathrm{a}-7 \mathrm{c}$ respectively, but overall the puncture damage is smaller and it might be due to the mechanical properties of $\mathrm{p}-\mathrm{AR}$ yarn. $\mathrm{P}-\mathrm{AR}$ yarn is a high tenacity yarn and has a moderate initial modulus which requires more energy to be cut and fractured and offers more elasticity to move the yarns from under the knife, minimizing 

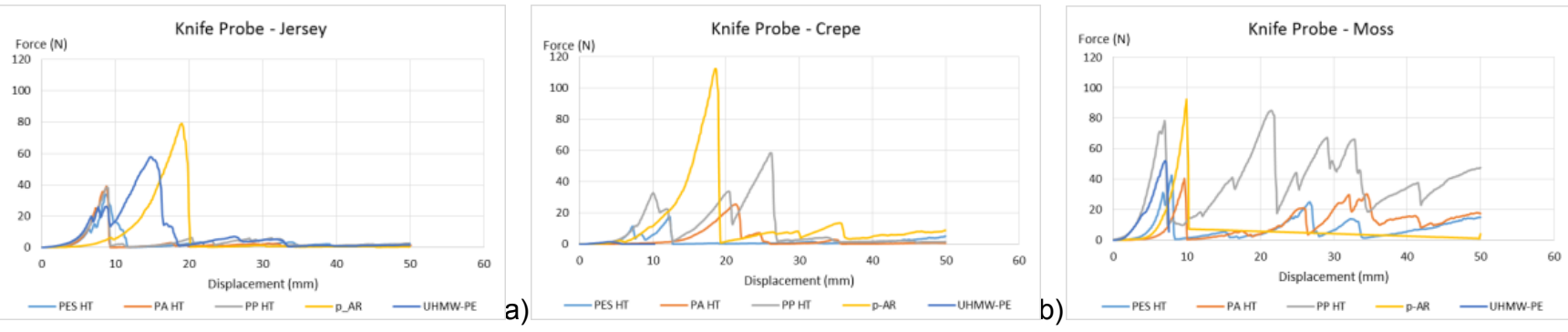

c)

Figure 6: Load-displacement curves for the weft knitted fabrics tested.

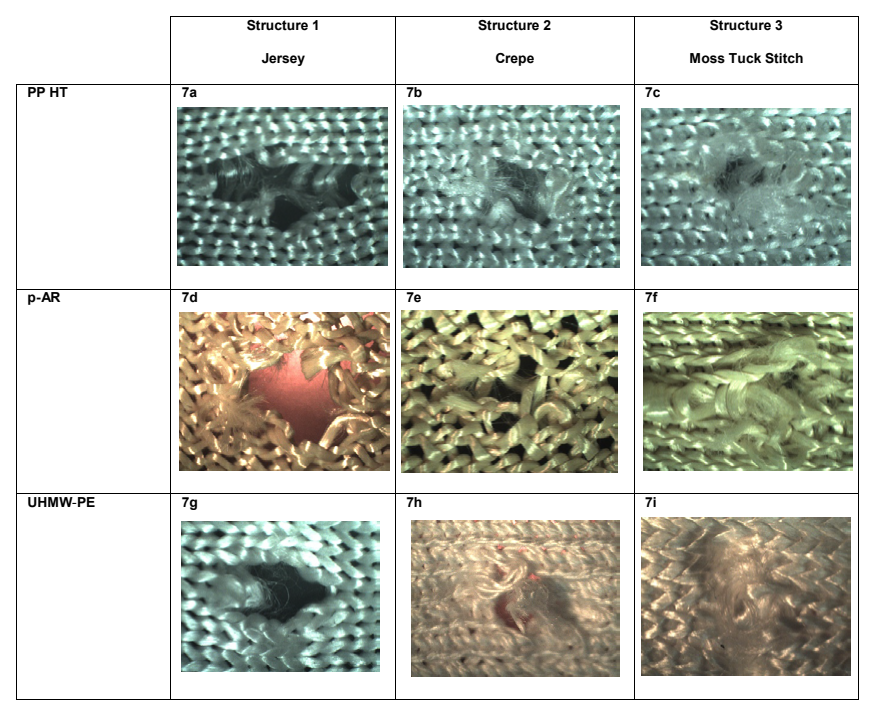

Figure 7: Jersey, crepe and moss knitted fabrics produced with PP HT, p- AR and UHMW-PE yarns after knife probe resistance test.

\begin{tabular}{|l|c|c|c|c|c|c|}
\hline \multirow{2}{*}{ Yarns } & \multicolumn{2}{|c|}{ Structure 1 (Jersey) } & \multicolumn{2}{c|}{ Structure 2 (Crepe) } & \multicolumn{2}{c|}{$\begin{array}{c}\text { Structure 3 } \\
\text { (Moss tuck stitch) }\end{array}$} \\
\cline { 2 - 7 } & Level & Cut index & Level & Cut index & Level & Cut index \\
\hline PES HT & 1 & 2.4 & 3 & 7.1 & 4 & 10.5 \\
\hline PA HT & 1 & 2.1 & 3 & 5.4 & 2 & 3.4 \\
\hline PP HT & 1 & 2.1 & 1 & 1.9 & 2 & 4.5 \\
\hline UHMW-PE & 4 & 3.4 & 4 & 15.4 & 5 & 33.4 \\
\hline p-AR & 2 & 10.9 & 5 & 21.1 & 5 & 48.4 \\
\hline
\end{tabular}

the fabric damage. Fabric damage presented in Figures $7 \mathrm{~g}-7 \mathrm{i}$ are comparable to fabric damage presented in Figures 7d-7f, respectively. The big difference being on the energy required to cut and fracture the yarns, fabrics produced with UHMW-PE yarn requires less energy than fabrics produced with p-AR yarns. UHMW-PE yarn is a high tenacity yarn and has a high initial modulus, which offers less elasticity to move the yarns from under the knife and the knife penetration occurs sooner.

Therefore the results confirm the literature review as the conical puncture resistance of a fabric is mainly attributed to the friction between the yarns and within the yarns, and the knife puncture resistance of a fabric is mainly attributed to the strength of the yarns [11].

\section{Cut resistance}

Cut resistance is defined as the ability of a material to resist damage when challenged with a moving sharp edge. The results presented in
Table 5, show the influence of the fabrics structure and of the yarn type. UHMW_PE moss tuck stitch fabrics present the highest cut resistance performance while the jersey fabrics the lowest. It is clear from Table 4 that the cut resistance index of UHMW_PE moss tuck stitch has increased considerably to the extent of $129 \%$, when compared with the same fabric made of crepe structure, and $344 \%$ when compared with jersey structure. The increase in cut resistance is attributed to the good stretch (the yarn moves and the blade actually slides across the yarn without catching it to cut) and thickness of structure 3 , in addition to the tensile strength of the yarn.

\section{Conclusions}

The effect of the weft knitted structure on the fabric puncture and cut resistance has not been investigated enough. Most work has focused particularly on multi-layered weft knitted fabrics $[3,12]$. The present study took into consideration the puncture and cut resistance behaviour of single-layer weft knitted fabrics (jersey, crepe and moss), produced with five types of high performance yarns (PES HT, PA HT, PP HT, UHMW-PE, and P-AR) in order to investigate the effect of the fabric structure on the mechanical protective performances. It was proved that due to the tuck stitches, crepe and moss structures improved cut and puncture performances in comparison with jersey structures. The conical puncture resistance of a single-layer knitted fabric was mainly attributed to the structure (high friction between the yarns and within the yarns due to the dense structure), the knife puncture resistance was mainly attributed to the strength of the yarns, and the cut resistance was mainly attributed to the structure (stretching and thickness) and to the yarns strength.

Based on the experimental results and on the EN 388 test classification, UHMW-PE moss tuck stitch structure present the highest cut resistance - level 5, and the highest conical puncture resistance - level 4. p-AR crepe structure presents the highest knife puncture resistance.

According to the results it is suggested the use of UHMW-PE single layer moss tuck stitch structure as protective clothing. Thermophysiological comfort properties, such as air permeability, water vapour permeability, thermal resistance, wick ability, absorbency, drying rate are being assessed on the UHMW-PE single-layer moss tuck stitch in order to study the relationship between comfort and protection.

\section{Acknowledgments}

This project has been funded by COMPETE/QREN under the Project No. $2014 / 38320$.

\section{References}

1. Dolez PI, Vu-Khanh T (2009) Recent developments and needs in materials used for personal protective equipment and their testing. International Journal of Occupational Safety and Ergonomics 15: 347-362. 
Citation: Fangueiro R, Carvalho R, Silveira D, Ferreira N, Ferreira C, et al. (2015) Development of High-performance Single Layer Weft Knitted Structures for Cut and Puncture Protection. J Textile Sci Eng 5: 225. doi:10.4172/2165-8064.1000225

2. Garcia V (2014) Sediment distribution patterns on the Galicia-Minho continental shelf.

3. Xuhong M, Xiangyong K, Gaoming J (2013) The experimental research on stab resistance of warp-knitted spacer fabric. Journal of Industrial Textiles 43: 281 301.

4. Flambard X, Polo J (2004) Stab resistance of multi-layers knitted structures. J Adv Mater 36: 30-35

5. Xiaolin Y, Guanxiong O, Yaming J (2011) Research on the stab resistant mechanism of the weft knitted fabrics. TianJin University, China.

6. Lijuan L, Gaoming J, Xuhong M (2011) Structure and properties of stab resistant warp knitted fabric. J Text Res 32: 48-51.

7. Spencer DJ (2001) Knitting Technology: A Comprehensive Handbook and Practical Guide (3rd edn.). Woodhead Publishing Limited, Cambridge England.
8. Triki E, Nguyen-Tri P, Gauvin C, Azaiez M, Vu-Khanh T, et al. (2015) Combined puncture/cutting of elastomer membranes by pointed blades: Charaterization of mechanisms. Journal of Applied Polymer Science.

9. Miao X, Jiang G, Kong X, Zhao S (2014) Experimental Investigation on the Stab Resistance of Warp Knitted Fabrics. Fibres \& textiles in Eastern Europe 5: $65-70$.

10. El Messiry M (2014) Investigation of Puncture Behaviour of Flexible Silk Fabric Composites for Soft Body Armour. Fibres \& textiles in Eastern Europe 5: 71-76.

11. Gong X, Xu Y, Zhu W, Xuan S, Jiang W, et al. (2014) Study of the knife stab and puncture-resistant performance for shear thickening fluid enhanced fabric. Journal of Composite Materials 48: 641-657.

12. Alpyildiz T, Rochery M, Kurbak A, Flambard X (2011) Stab and cut resistance of knitted structures: a comparative study. Textile Research Journal 81: 205-214. 